\title{
THE CONTENT KNOWLEDGE ABILITY OF SCIENCE TEACHER CANDIDATES: THE ANALYSIS OF LEARNING MEDIADEVELOPMENT
}

\author{
Lina Arifah Fitriyah ${ }^{1}$, Nur Hayati ${ }^{2}$, Andri Wahyu Wijayadi ${ }^{3}$ \\ 1,2,3 Program Studi Pendidikan IPA, Fakultas Ilmu Pendidikan, Universitas Hasyim Asy'ari Tebuireng Jombang \\ Jawa Timur, 61471, Indonesia \\ linaarifahfitriyah@gmail.com ${ }^{1}$, nurhay.ht@gmail.com ${ }^{2}$,diaandri@gmail.com ${ }^{3}$
}

Accepted: October 1, 2020

Published: October 31, 2020

DOI: https://doi.org/1921107/jps.v7i2.7995

\begin{abstract}
In the teaching and learning process, an educator must be creative and can use engaging learning media. Learning media is expected to be able to help educators to deliver the subject matter well. Therefore, an educator (teacher) must have the minimum skills, proficiency, and expertise that meet specific standards and competencies. One of the gifts is content knowledge. Content Knowledge (CK) is the initial ability of an educator that should be mastered in mastering learning material (understanding of material concepts). To master the ability of good content knowledge in science teacher candidates, one can see from the students' ability to create and compile learning media. This study aims to: determine (1) the ability of content knowledge of science teacher candidates in making learning media based on indicators, and (2) the significance of content knowledge of science teacher candidates in making learning media. The research method used is a quantitative description. The research subjects were 15 students of the Science Education Study Program in the academic year 2018. The research instrument used was the content knowledge assessment sheet. The results showed that: (a) the ease of media used $75.73 \%$ (good category), the suitability of the media with the characteristics of students $77.53 \%$ (good), the accuracy of the media with the material and learning objectives $73 \%$ (good), and the attractiveness of the media $80.67 \%$ (well). It also showed that $(b)$ there is a significant difference in students' content knowledge in making learning media with significant value (2-tailed) $<0,05$, which is 0,000 .
\end{abstract}

Keywords: Content Knowledge, Learning Media Making, Science Teacher Candidates

\footnotetext{
${ }^{1}$ Corresponding Author
} 


\section{Introduction}

In the learning process, an educator is required to be creative and use interesting learning media. It is expected to be able to help educators to deliver the subject matter well.

The submission of subject matter can be integrated using the learning media. It can clarify the presentation's messages and information to expedite the learning process and stimulate the mind, feelings, attention, and willingness of students to encourage the learning process. Thus, the learning process becomes more evident, more interesting, interactive, and time and energy efficiency.

An educator (teacher) must have the proficiency, expertise, and minimal skills that meet certain standards and competencies. The regulation of the Minister of National Education of the Republic of Indonesia Number 16 the Year 2007 regarding The Academic Qualification Standards and Teacher Competencies divides teacher competencies into pedagogical, personality, professional, and social competencies. Rusilowati et al. (2012) explained that teacher candidates need to be equipped to teach by integrating skills that can empower students. These skills include utilizing the media and the classroom environment, using student worksheets, and integrating characters into the subject matter.

Professional educators know the content and pedagogical and have an integration of both, known as Pedagogical Content Knowledge (PCK) (Shulman, 1986; Lee \& Lutfi, 2008). Etkina (2010) made it clear in her research that Content Knowledge (CK) is the educator's initial ability to master learning material. Pedagogical Knowledge $(\mathrm{PK})$ is the ability of an educator of media, learning models/ strategies, and learning evaluation.

Good CK skills in the students of science teacher candidates can be seen from students' ability to create and compile learning media. The selection of a good learning media are: (1) the accuracy of the learning media with the material and learning objectives, (2) the suitability of the media with the characteristics of students, (3) the ease of use of learning media, and (4) the attractiveness of the media used.

It is necessary to research the Content Knowledge (CK) ability of the science teacher candidates in making and compiling learning media. The purpose of this study was to (1) determine the ability of content knowledge in the students of science teacher candidates in making media based on the indicators, and (2) the significant content knowledge of it.

\section{Research Method}

The research method used is a quantitative description. The research subjects were 15 students of the Science Education Study Program in the academic year 2018. The data collection techniques used were observation. According to Arikunto (2012), observation is a technique carried out by systematically making careful observations and recording. The research instrument used was the content knowledge assessment sheet. It has four aspects of assessment that can be seen in Table 1.

Table 1. Assessment Aspect and Indicators of Content Knowledge in Media Making

\begin{tabular}{|c|c|}
\hline $\begin{array}{l}\text { Assessment } \\
\text { Aspects }\end{array}$ & Indicators \\
\hline $\begin{array}{l}\text { Media } \\
\text { Knowledge }\end{array}$ & $\begin{array}{l}\text { 1. The accuracy of the learning } \\
\text { media with the material and } \\
\text { learning objectives } \\
\text { 2. The suitability of the media } \\
\text { with the characteristics of } \\
\text { students }\end{array}$ \\
\hline $\begin{array}{l}\text { Media } \\
\text { Development }\end{array}$ & $\begin{array}{l}\text { 3. The ease of learning media } \\
\text { using } \\
\text { 4. The attractiveness of the media } \\
\text { used }\end{array}$ \\
\hline
\end{tabular}

Table 2 is the criteria to determine the percentage range of scores for the student content knowledge indicators in making media.

Table 2. The Criteria of Content Knowledge Assessment

\begin{tabular}{cc}
\hline Percentage & Criteria \\
\hline $81-100$ & Very Good \\
$61-80$ & Good \\
$41-60$ & Quiet Good \\
$21-40$ & Less Good \\
$0-20$ & Not Good \\
\hline
\end{tabular}

(Derived from Akbar, 2013)

The data analysis was performed with the help of the SPSS for Windows program. The research hypothesis will be tested with a T-test with a significance level of 0.05 by using the data content knowledge of the students of science teacher candidates in making and compiling learning media.

\section{Result and Discussion}

The research data were obtained from 15 students of Science Education Study Program students at the Faculty of Education, Hasyim 
Asy'ari University, Tebuireng Jombang. The description of the data content knowledge indicator can be seen in Figure 1.

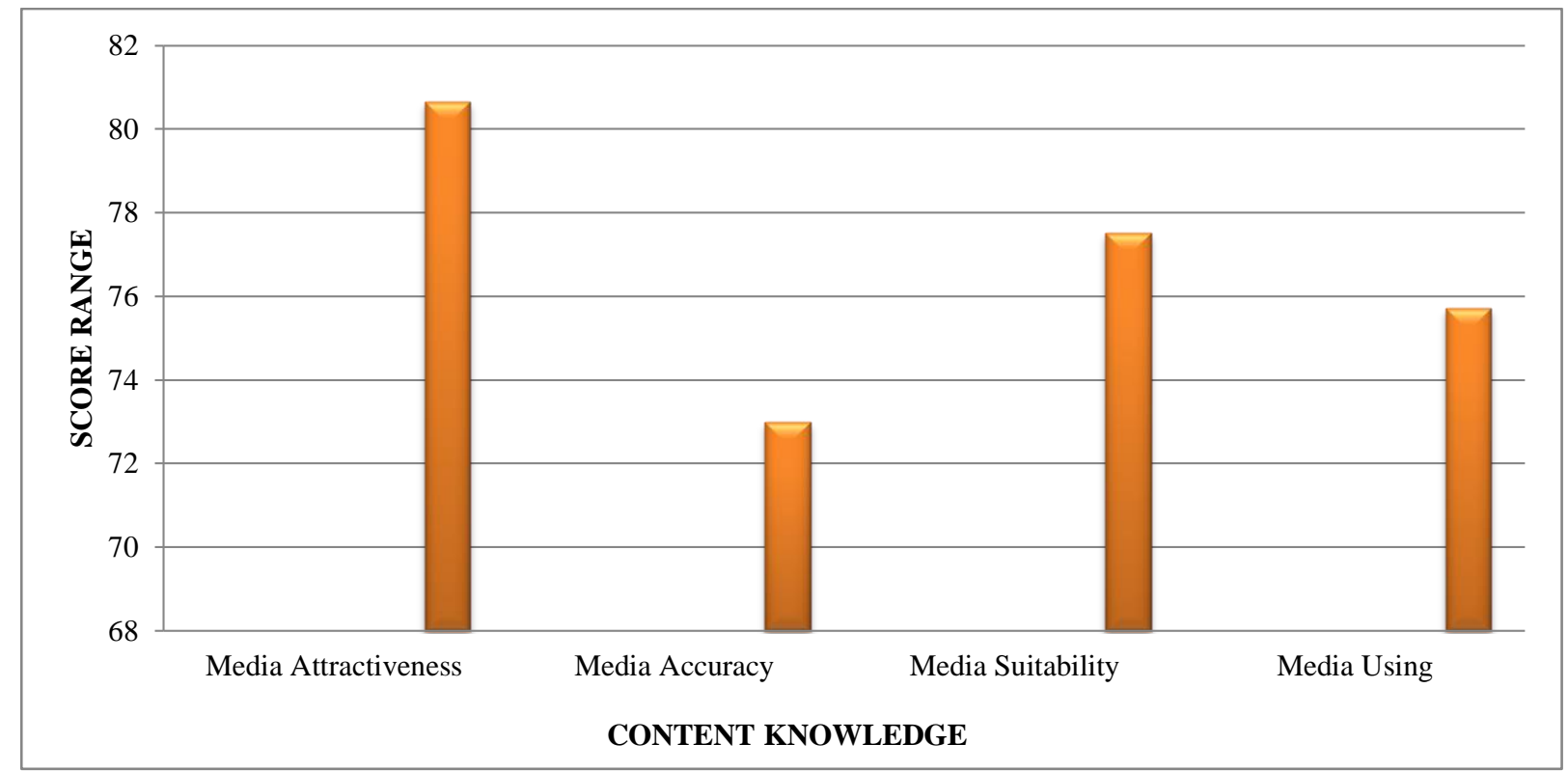

Figure 1. The Percentage of Content Knowledge Each Indicator

Based on Figure 1, it can be seen that overall the average percentage of student skills in making learning media is good. There are $75.73 \%$ of students who can make learning media with the technical use of media, and $73 \%$ of media that are made are right according to the material and learning objectives, which is the learning competence of science subjects in SMP / MTs. As many as $77.53 \%$ of the science media created by students follow the age of SMP/ MTs students, and $80.67 \%$ of the media can attract and enthusiast the audience when their friends act as students. At the same time, the media maker works as a teacher.

The percentage results of the content knowledge based on media making indicators showed a good criterion. In general, they have been represented in preparing and utilizing learning media.

This can be seen from students' ability to choose the type of learning media that has been well designed, and students can practice it in front of the class. The examples of media made by students are food web cards. Forty-eight cards are consisting of producers, consumers, analysts, and decomposers. The card must be played by several people (1-4) as well as playing a "Remi" or a "Domino" card. The card that is shown by one of the players for the first time is a producer card, displayed based on the existing pictures on cards. Then the other players must deposit consumers, analysts, and decomposer cards. For those who finish the cards quickly or the cards held by the player are already held up, then he/ she is said to be the winner, for the loser is the player who still has cards at the most.

Rahmawati (2015) argues that if learning is adequately designed concerning learning objectives, methods, teaching materials, and selecting appropriate media and teacher skills in practice, the learning outcomes will be optimal. Science learning by using instructional media can reduce teachers' dominance for lectures commonly used in daily education. Thus, students also have more time to carry out activities or the teacher's tasks to discuss related to the material that is integrated using learning media.

Some learning media created by students can be seen in Figure 2.
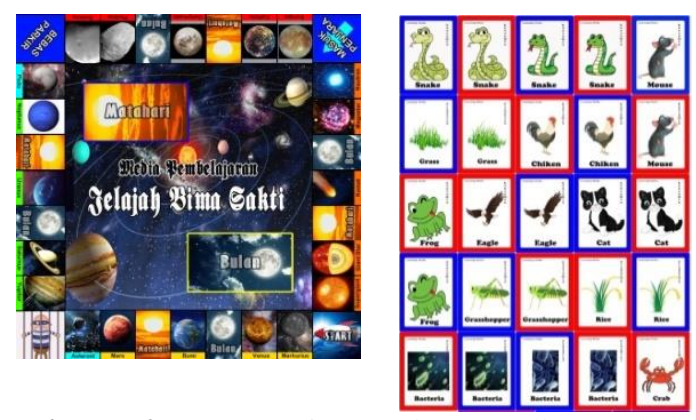

Figure 2. Types of Learning Media Made by Students

The T-test analysis results were carried out to find out whether there were differences in students' content knowledge in making learning media. T-test results can be seen in Table 2 . 
Based on the T-test result in Table 2, it is known that the average score of content knowledge in learning media is 76,800 , with details of each indicator of competent knowledge. Those are: (1) media that shod be attractive with an average score of $80.667,(2)$ the media made should work under materials and learning objectives in the SMP / MTs curriculum with a score of 72.667 , (3) the media made should according to the character of SMP /
MTS students with a score of 77.533, and (4) the media made should be easy to be used with a score of 75.733. Thus, overall, students can make excellent and creative media in learning science in the classroom.

Table 3. T-Test Result

\begin{tabular}{lccc}
\hline \multicolumn{1}{c}{ Content Knowledge of Learning Media } & Mean & t & Sig. (2-tailed) \\
\hline The attractiveness of media used & 80,667 & 32.505 & .000 \\
\hline $\begin{array}{l}\text { The accuracy of the learning media with the } \\
\text { material and learning objectives }\end{array}$ & 72,667 & 14.543 & .000 \\
\hline $\begin{array}{l}\text { The suitability of the media with the characteristics } \\
\text { of students }\end{array}$ & 77,533 & 27.333 & .000 \\
\hline $\begin{array}{l}\text { The ease of learning media using } \\
\text { The average Score of Media Indicators }\end{array}$ & 75,733 & 17.438 & .000 \\
\hline
\end{tabular}

Wasilah (2012) states that the media used in learning must be precise and exciting. Through the use of media, learning can be effective, creative, and fun for students. Learning without using media tends to make students are less focused when educators explain the material (Elpira \& Gufron, 2015).

The significant value (2-tailed) $<0.05$ is 0,000 . It shows that there is a significant difference in students' content knowledge in making learning media. The student of science teacher candidates can adjust the media made according to the material's scope, learning objectives, and the ease of media used. Therefore, the media is needed in learning, especially certain materials that must be explained by using media; it is easier for students to understand and have the motivation to learn science (Elpira \& Gufron, 2015).

Ibrahim and Syaodih (2003) explained that the factors for choosing the right media included: (1) whether the learning objectives made the media, (2) the use of the media made, (3) the ability of teachers to use the media, (4) how practical the media is used, (5) media availability, (6) compatibility with the time and supporting facilities, and (7) costs.

Abell (2007) states that the pedagogical content knowledge (PCK) of science teacher candidates influences learning orientation, concept understanding, media use, and scope. They must be accustomed to using instructional media in teaching practices (Aminah \& Wahyuni, 2018).

Therefore, mentoring and training teacher candidates have endeavored as initial experience in developing their abilities (Marble, 2007). The guidance is expected for future students to be recognized and valued as teachers. They are motivated and earnest with their abilities and skills to realize the quality of education (Sepriyanti, 2012).

\section{Conclusion}

Based on the results of research, the conclusion can be drawn that the ability of content knowledge of the student of science teacher candidates of the Faculty of Education in Unhasy is categorized as good with the percentage; (1) The ease of media used is $75.73 \%$, (2) The suitability of the media with the characteristics of students is $77.53 \%$, (3) The accuracy of the learning media with the material and learning objectives is $73 \%$, and (4) The attractiveness of the media used is $80.67 \%$. The T-test result shows that the significant value (2-tailed) $<0.05$ is 0,000 , which means a significant difference in students' content knowledge in making learning media. As for the further research's suggestions are it is necessary to do further research on students both regarding the ability of Pedagogical Knowledge (PK) and Content Knowledge (CK) or the combination of both, known as the ability of Pedagogical Content Knowledge (PCK). In conducting lectures, lecturers are always expected to emphasize understanding of knowledge content and mastering pedagogical knowledge to obtain quality graduates who can compete in the world of work. 


\section{Acknowledgment}

The author would like to thank the Directorate of Research and Community Service (DRPM), Deputy for Research and Technology Strengthening Ministry of Research and Technology / National Research and Innovation Agency (Ristek-Brin), which has provided researchers the opportunity to obtain grants in the novice lecturer research scheme and to Hasyim Asy'ari University, Tebuireng Jombang, which has facilitated this research and also other parties who have helped.

\section{References}

Abell, S. L. (2007). Research on Science Teachers' Knowledge. In S.K. Abell \& N.G. Lederman (Eds.), Handbook of Research On Science Education (pp. 1105-1149). Mhawah, NJ: Lawrence Erlbaum Associates.

Aminah, N., Wahyuni, I. (2018). Kemampuan Pedagogic Content Knowledge (PCK) Calon Guru Matematika Pada Program Pengalaman Lapangan di SMP/SMA Negeri Kota Cirebon. JNPM (Jurnal Nasional Pendidikan Matematika), 2(2), 259-267.

Elpira, N., \& Ghufron, A. (2015). Pengaruh Penggunaan Media Powerpoint Terhadap Minat Dan Hasil Belajar IPA Siswa Kelas IV SD. Jurnal Inovasi Teknologi Pendidikan, 2(1), 94-104.

Etkina, E. (2010). "Pedagogical Content Knowledge and Preparation of High School Physics Teacher." Physical Review Special Topics-Physics Educations Research.

Peraturan Menteri Pendidikan Nasional Republik Indonesia Nomor 16 Tahun 2007 tentang Standar Kualifikasi Akademik dan Kompetensi Guru.

Rahmawati, R. (2015). Keterampilan Calon Guru SD Dalam Menerapkan Media Pembelajaran IPA Berbasis IT Terhadap Hasil Belajar Siswa SDN 5 Panarung Palangka Raya. Anterior Jurnal, 15(1), 62-69.

Rusilowati, A., Hartono, Supriyadi. (2012). Pengembangan Model Pembelajaran Better Teaching and Learning Berkarakter untuk Membekali Kompetensi Pedagogi Mahasiswa Calon Guru. Jurnal Penelitian
Pendidikan. Vol.29 No.2 Hal.8392. Semarang: LP2M Unnes.

Sepriyanti, N. (2012). Guru Profesional adalah Kunci Mewujudkan Pendidikan Berkualitas. Jurnal Al-Ta'lim, 1(1), 66-73. DOI: 10.15548/jt.v19i1.8.

Shulman, L. (1986). Those who understand: Knowledge growth in teaching. Educational Researcher, 15(2), 4-14.

Ibrahim \& Syaodih, N. (2003). Perencanaan Pengajaran. Jakarta: Rineka Cipta.

Lee, E., \& Luft. J.A., (2008). "Experienced Secondary Science Teachers' Representation of Pedagogical Content Knowledge." International Journal of Science Education, 30 (10):1343-1363.

Marble, S. (2007). Inquiry into Teaching Lesson Study in Elementary Science Methods. Journal of Science Teacher Education, 18, 935-953.

Wasilah, E. B. (2012). Peningkatan Kemampuan Menyimpulkan Hasil Praktikum IPA melalui Penggunaan Media Kartu. Jurnal Pendidikan IPA Indonesia, 1(1). 